\title{
The Cultural Turn in Gerontology
}

Chris Gilleard and Paul Higgs

The aim of this chapter is to set cultural gerontology within the context of the broader 'cultural turn' in the social sciences. Although there were earlier precursors who wrote about the importance of cultural processes for the study of social signification and distinction, such as Clifford Geertz, Michel Foucault and Pierre Bourdieu, the cultural turn became more evident during the 1990s with the growing interest in the ideas of post-structuralism and postmodernism as sociological rather than aesthetic or literary phenomena. The work of Zygmunt Bauman, Ulrich Beck and Anthony Giddens became leading theoretical reference points for European sociology during this period (Outhwaite, 2009) exemplified a new approach focussing on themes of contingency, individualisation and reflexivity in social analysis. These and other writers agreed that a fundamental change was taking place in the organisation of modern society, a change that undermined the certainties of the modern nation state. The outcomes generated by this change were to be found in increasing fluidity, indeterminacy and reflexivity in the formation and exercise of social identities and individual lifestyles. Identity became an important issue, but significantly it could no longer be seen to map unproblematically onto the distinct socio-economic categories established in the previous phase of modernity. All that once seemed solid about the institutions of modernity was now in flux.

Although each of the above sociologists emphasised different aspects and different vectors of what could be described as 'post-modern' change, they broadly agreed on presaging it upon: (a) the transformation of national economies from those based upon industrial capital and 
mass production to those based around mass consumption; (b) cultural and economic globalisation; (c) the disembedding influences of the market and the media; and (d) new social movements. The latter, particularly, stimulated new academic disciplines subsumed under the rubric of 'cultural studies'. In contrast to the emphasis on social class, deviance and status in the mainstream social sciences, cultural studies drew attention to the 'covert' positionalities and subjectivities of variously gendered, racialised, sexualised and disabled bodies. Socially, culturally and academically, greater attention was paid to the body as a source of identity and expression of lifestyle. These embodied identities were viewed through the critical prisms of power and performativity. Rather than accepting as 'natural' the corporeal binaries of gender, race, sexuality and able-bodiedness, the contingency and fluidity of 'embodied' signification was explored through gender and women's studies, studies of race and ethnicity, of sex and sexuality and through disability studies. While initially focusing on youthful bodies, these new fields of academic inquiry began to impact upon the study of age and ageing (Gilleard and Higgs 2013). Such 'thinking through the body' has caused similar questions to be raised about age and ageing as were asked about sex and gender, ethnicity and race, impairment and disability. The hegemony of the 'youth versus age' paradigm that previously dominated gerontological thinking in the twentieth century is beginning to be challenged as the social identity of old age fragments.

Perhaps the first impetus for re-examining ageing 'through the body' was provided by women's studies. A number of feminist gerontologists began to argue that it was no longer satisfactory to speak about ageing as if it were a reified phenomenon unrelated to particular individual bodies embodying particular identities. Such questioning first began in articles published in the 1970s and 1980s (Sontag, 1972; Olson, 1988), but taking a thoroughly gendered lens to ageing was primarily a phenomenon of the 1990s (Venn, Davidson and 
Arber, 2011: 72-3). This was most strongly highlighted when, in 1993, a special issue of the Journal of Aging Studies was published devoted to the new 'feminist' gerontology. In reviewing what was being realised in this issue, Beth Hess made clear that the papers assembled enabled gender at last to be treated as a phenomenon of 'the social relations of age' and not simply the product of individual differences in ageing (Hess, 1993: 196). Coming from outside the sphere of ageing studies, cultural sociologists such as Mike Featherstone and Mike Hepworth were also beginning to extend their interest in the body and consumer society to the concerns of those with ageing bodies (Featherstone and Hepworth, 1991). Remarkably, this chapter occurred in one of the first edited collections on the sociology of the body (Featherstone, Hepworth and Turner, 1991), something that many subsequent collections in this growing subfield have failed to pursue.

Both perspectives have helped re-position the study of age and ageing towards the adoption of a more explicitly cultural approach, at the same time as drawing attention to age's embodied nature. The cultural sociology of consumerism and the sociology of gender independently have helped to widen the door to other ways of examining age and ageing beyond the chronological traditions of gerontology. Subsequently, not only gender but race, ethnicity, sexuality and disability have been used to re-examine previously unquestioned assumptions about ageing and later life. Age is now being seen through the lens of 'intersectionality', the cross-disciplinary arena that sees social phenomena through the lenses of the multiple identities and positions that destabilise and render contingent dominant interpretations of later life. In a similar fashion, cultural sociology has encouraged the positioning of older people not as happy or unhappy, healthy or unhealthy, fit or frail individuals but as agentic, contradictory and potentially desiring subjects who are both implicated in, as well as being contributors to contemporary culture and the individualised, 
consumerist 'project of the self' (Giddens, 1991). Such perspectives have consequently encouraged social science researchers to go out and explore changing patterns of consumption, to research time use, to study 'body work' and 'self-care' as well investigate many other related lifestyle practices in later life.

\section{Consumption, culture and the politics of post-modernity}

Instead of the word 'postmodernity', sociologists such as Bauman, Beck and Giddens chose other terms, such as 'post-traditional or reflexive modernity' (Giddens, 1991) 'liquid modernity' (Bauman, 2000: 2005), 'second' modernity or even 'after' modernity (Beck; 1999; Beck and Grande, 2010) to describe the social economic and cultural arrangements of present day society. Despite the differing nomenclature they have each contributed to the creation of a language in which the changed nature of society could be discussed. Beck wrote about a first (classical, industrial) modernity and a second (reflexive, post-industrial) modernity. The latter he delineated through the five inter-linked processes of globalisation, individualization, gender revolution, underemployment and global risk (Beck, 1999: 2). The simultaneous operation of these five processes has undermined the solid structures of the modern world of the nation state. While much of Beck's work around the idea of 'risk society' was concerned with institutionalisation of 'individualisation' within specific societies (Beck and Beck-Gernsheim 2001), he also paid attention to the effects of globalisation and the limitations of the nation state. 'Globality' as he termed it represents the expansion and ever greater density of international trade, the revolution in information and communications technology, universal demands for human rights and a post-national polycentric world politics 'where transcultural conflicts are enacted in one and the same place' (Beck, 2000: 11-12). The nation state and the institutions through which it operates no 
longer have the dominating influence that they had during the late nineteenth and early twentieth centuries (Beck and Lau 2005).

For Bauman, much as Beck's second modernity had replaced first modernity, a new 'liquid' modernity had replaced the old 'solid' modernity. Like Beck, he viewed this new liquid form as an 'individualized, privatized version of modernity' where 'the burden of pattern weaving and the responsibility for failure fall[s] primarily on the individual's shoulders' (Bauman, 2000: 8). The transformation of solid into liquid modernity is also seen by Bauman as a consequence of the impact of individualization, as well as resulting from changes in the ordering of time and space, along with the replacement of stable with fluid communities, changes to the nature of work, and the shift from building future structures to the playing of games (Bauman, 2000:138). Equally an emphasis upon ‘emancipation' which he describes as 'the need for self-determination' has played a role in transforming social reality. In a later work, he has summarised this transformation as a shift from a society of producers to a society of consumers. In liquid modernity, he argues, the 'consumerist syndrome' determines 'virtually all the parts of the social setting and of the actions they evoke' (Bauman, 2005: 83).

For Giddens, who was writing before either Beck or Bauman had fully formulated their approaches, the transition is less about consumerism and more about a shift towards a new 'life politics' at the centre of which lies 'the reflexive project of the self' (Giddens, 1991: 237). In life politics, social conflicts were as much over meanings as they were over resources - particularly the struggle to free oneself from the oppressiveness of ascribed identities and assigned communities. But, as Giddens noted, such struggles were fraught with conflicts. They risk diverting attention, and concern, away from those without the material 
resources to realise their 'self-project' to those with the means to do so, while increasing opportunities for the market to commodify individuals' life choices and lifestyles (Giddens, 1991: 196-200). Giddens particularly addressed the shift in the 'referentiality' of the lifespan which he viewed as an important consequence of the 'disembedding' of tradition. He concluded that as a consequence 'the lifespan becomes more and more freed from externalities associated with pre-established ties to other individuals and groups' and that 'lacking the external referents supplied by others, the lifespan again emerges as a trajectory which relates above all to the individual's projects and plans' (Giddens, 1991: 147). Specifically discussing later life, Giddens sees that 'old age at sixty-five is a creation, pure and simple, of the welfare state' whereby 'ageing is treated as "external" as something that happens to one not as a phenomenon actively constructed and negotiated' (Giddens, 1994: 170). Instead, he suggests, there is a need for 'a politics of second chances' that offers opportunities for rethinking and repositioning later life (Giddens, 1994: 172).

Three themes unite these three theorists. Each saw the transition or change in the nature of modernity less as a purely structural one and more as one over-determined by culture and with this went the superseding of production-based collective approaches by individualised consumer 'mentalities'. Previous habits and collective traditions framed by the institutions of the workplace and the state were transformed by the profusion of choice provided by the market operating alongside an increasing reflexivity that celebrated individual choice and the exercise of personal agency. All three implicated the power of globalisation in facilitating this change, both through the expansion of the global market for goods and services as well as the limiting of the discretionary powers of the nation state. For these canonical theorists there has been an acceptance that the nation state could no longer serve as the principle determining influence organising individual life courses. In various ways their work 
combines to argue for the institutionalisation of individualisation, the necessity for continual reflexivity and the ever present valorisation of choice, with all the intended and unintended consequences that such 'emancipation' might bring throughout the life course.

\section{Liquid ageing: the destandardisation of the life course.}

If, as Giddens has suggested, new opportunities - second chances - are being realised to age differently in second modernity, what might the main influences on this 'destandardisation' of later life be? Drawing upon the theoretical writings of Bauman, Beck and Giddens, we have previously postulated that these 'opportunities' have arisen through several inter-related 'vectors' of change that have characterised post-war Western society. Foremost among these has been the expansion of mass consumerism, alongside the rise of new social movements associated with the cultural ferment of the 1960s, the changing social geography of life and the changing nature of work and retirement (Gilleard and Higgs, 2005; 2011a).

A mass consumer society emerged in a number of Western countries during the decades after the Second World War. Those initially most affected by and most involved in the expanding markets for consumerist goods and services were younger adults, but as these young adults grew older they remained major consumers (Higgs et al., 2009). Not only did the numbers and ages of consumers grow so too did the arenas in which consumerism was realisable. Fashion for all ages jostled with cosmetics and cosmetic surgery for all ages (Twigg 2013). The disposable income of people over sixty has grown at a rate either matching or more often exceeding that of people of 'working age' since the 1980s (Wolf, Zacharias and Masterson, 2012). Despite the financial crisis of the early twenty first century, the proportions of 
pensioners in the UK in each of the five income quintiles is now broadly similar to that of the general population (DWP, 2012). Similar changes can be found across most Western societies evincing the novelty that "older persons constitute an increasing consumer group with... significant aggregate purchasing power' '(UNECE, 2009: 1).

Young adults were imbricated in the cultural transformation of the post-war era as much through the new social movements that emerged in or shortly after the 1960s as through their rising discretionary income. United under the slogan that the 'personal was political', the women's liberation, the black civil rights and the gay liberation movements asserted the voices of groups of people who previously had suffered varying degrees of cultural, economic and social marginalisation within 'modern' societies that had traditionally valorised the position of the white, male, middle aged, heterosexual breadwinner. Equality of access to the main institutions of society - of the state, the workplace and the market - was legislated for enabling increasing degrees of 'inclusion' for people embodied by difference. In a similar fashion to participation in consumer culture, although these 'life politics' affected younger adults first, the subsequent ageing of these youth sub-cultures saw issues of identity and lifestyle extend across the life course into mid-and later life (Gilleard and Higgs, 2011b; Hodkinson, 2013)

Changing social geographies have also contributed to changing the place of age in society. The communities of place built up during the course of what Beck has termed 'first modernity' have given way to the new communities of identity and interest (Gilleard and Higgs, 2005). Social communication relies less upon 'the propinquity of neighbourhoods' and more upon access to Information and Communication Technology (ICT). The 'network' 
society described so extensively by Castells (1996) has removed the dependency of social interaction to be based on physical proximity. It has established new patterns of interrelatedness that obfuscate time and place and in so doing break down some of the 'rhythmicity' of life and the life course. As Castell noted '[w]hile old age was once considered a homogenous last stage of life... dominated by 'social death' it is now a highly diverse universe' fostered by the development of the new network society (Castells, 1996: 446).

Several developments illustrate this trend. First is the growth in 'senior citizen' tourism, in retiree seasonal migration and in transnational home ownership and home rentals particularly by late life couples. Second is the growth in older people's use of mobile (cell) phones, of the Internet and of Internet enabled telecommunications (such as Skype) and social media. Third is the growth amongst the older population in various interest based 'outdoor' pursuits ranging from sporting activities (such as the rise of master athletes) to cultural events (such as the growth of 'retro-concerts' and 'book clubs' or 'reading groups') to educational activities (such as 'Universities of the Third Age) . There are no doubt many more examples facilitated both by greater disposable incomes, by developments in domestic ICT and by active state policies directed toward improving access (such as subsiding the costs of travel for senior citizens). While those at both ends of the life cycle remain more dependent upon propinquity based social resources than those in the middle, the network society and has a potential emancipatory capacity to free individuals from the limits of neighbourhood continues to impact upon all stages and ages in the 'post-modern' life course. 
Finally there is work. If the life course of first modernity was based upon the standardised working life of a white heterosexually partnered male employed in industrial labour, in second modernity no such singular model can prevail. The middle class white collar worker may be an aspirational figure but his pervasiveness is as under threat, as was the previous blue collar post-holder. Gender divisions have reduced, while sexual identities have diversified. Working lives have shrunk (at both ends), and racialised segregation has diminished as the nature of the place of work has been transformed. The result is a mixture of individual emancipatory gains and collectivised social losses. In the United States, the corporate (or work-based) welfare system is fast becoming a memory, alongside some selective forgetting of its exclusionary practices. Work based collective pension schemes are declining particularly in the 'Anglo-Saxon' economies. Even within the welfare states of continental Europe a guaranteed job and a guaranteed retirement age and income are under considerable threat. The 'three pillar' pension model espoused by the World Bank, comprising a poverty prevention state pension, an income stabilising occupational pension and an additional flexible income return from a private pension seems increasingly unrealisable for the majority of workers with "“"[p]ension reforms in many countries ...result[ing] in more choice and risk to individuals" (Gough and Niza, 2011: 97), The future of retirement is less certain as the outcome of pension reforms grows steadily more opaque (Grech, 2013).

Despite the growing uncertainties surrounding the source and size of income in later life, the risk of becoming impoverished in later life has been attenuated.Declining rates of poverty in later life, evident since the 1980s show no sign of being reversed in the twenty-first century (Figari, Matsaganis, and Sutherland, 2011; Grech, 2013; Zaida, 2009, 2010). As the division between working and non-working life again beginsto blur and as individuals are increasingly 
expected to shoulder the responsibility for ensuring an adequate income throughout their entire adult lives, the reading off of retirement from previous occupation becomes ever more contingent and open to alternative meanings. In short, class framed in terms of labour market position seems to matter less in understanding contemporary later lifestyles - even as later life inequalities increase. Lifecycles are not what they once were, and later lifestyles even less so.

\section{The Cultural Turn in Ageing Studies: Opportunities and risks}

The rise of consumer society has witnessed position and status transformed into lifestyle. Cultural and consumer practices have moved centre stage. This is the case at most if not all points in the life course, including later life. The cultural turn both reflects and reinforces the fracturing of a 'modern' discipline (gerontology) and of a 'modern' social group (the old). In place of the traditional dualism of chronology and corporeality, later life is now being examined through alternative lenses, through consumption and lifestyle, technologies of the self, and the life politics of identity. While these themes have stimulated much interesting and innovative research, both empirical and theoretical, the cultural turn has not been short of its critics. Within mainstream sociology, Will Atkinson has recently castigated Bauman, Beck and Giddens for preferring 'the shifting sands of rhetoric... [to]... the firm foundations of observed reality' (Atkinson, 2010: 32). 'Whatever the age and no matter the occupational position', he argues, 'the firm grip of class... has been shown to remain unbroken' (Atkinson, 2010: 32). Whatever the class, one might equally add, the firm grip of age has likewise remained unbroken. The anti-culturalist argument persists that society remains structured by age, sex and class and that understanding age without reference to the biology of ageing and the class structure of society is either misguided, perverse or simply superficial. 
International social survey research does not support such a structuralist analysis. Neither age nor class feature as salient sources of identity for over two thirds of the population of Western societies (Hyde, 2013: 83). For people no longer part of the labour force, no longer directly engaged with the social relations of production, it might be thought that property ownership could stand as a proxy for 'class'. But the division between a property owning and a property less class changed remarkably over the course of the last century. At the beginning of the twentieth century, the aged working poor were unable to own anything beyond the clothes on their back; by its end, home ownership was the 'norm' for people of retirement age, in France, in the United Kingdom and in the United States. While there are continuing debates about the usefulness of the term 'class' in contemporary sociology, the structures of class characterising 'first' modernity no longer seem so stable nor so relevant (Higgs and Formosa 2013). Instead we have inequality and diversity in later life, equally unjust but in different guises from the inequalities structured by $20^{\text {th }}$ century colonialism and industrial capitalism.

\section{Conclusion}

Foucault's 'late work' can serve as an important point of reference in charting these changing times. Although his earlier work was preoccupied by the nature of knowledge and power, he became more interested in ideas of 'governmentality' and 'self-care' later in life themes that are of particular relevance to a cultural gerontology. He began to examine what he identified as the 'practices of freedom', reframing power as 'strategic games between liberties' with technologies of governance mediating between these games and the particular states of domination that apply at any point in time or place (Foucault, 1994: 19). Age and ageing can 
be seen as sites for these kinds of 'strategic games' whether played out between corporeality and embodiment, or between states and markets, or between communities and individuals. Cultural gerontology we would argue should place these strategic games at the centre of its concerns - exploring the various agonistic struggles between asserting against ignoring chronological age, between privileging or de-emphasising ageing over able-bodiedness, sexual identity, gender or race, between an ageing that is shaped by the market and one that is shaped by the state. At the same time it is important that cultural gerontology recognises the contingencies and temporalities that determine the individual outcomes of these struggles. There is no final resolution for the place of age in society anymore than there is any final resolution of the power age exercises over individuals' lives. But by exploring these struggles, cultural gerontology can only enrich our understanding of the present and possible cultures of ageing. Such struggles involve continually transforming and re-organising issues of selfhood, citizenship and embodiment, struggles that extend over what Deleuze and Guattari (2004) called a thousand plateaus of inscription and re-inscription. The present handbook offers a glimpse of these plateaux, and will hopefully encourage others to explore and challenge them as they emerge.

\section{References}

Bauman, Zygmunt. 2000. Liquid Modernity. Polity Press, Cambridge.

Bauman, Zygmunt. 2005. Liquid Life. Polity Press, Cambridge. 
Beck, Ulrich. 1999. World Risk Society. Polity Press, Cambridge.

Beck, Ulrich and Beck-Gernsheim, Elisabeth 2001. Individualization: Institutionalised individualism and its Social and Political Consequences, London: Sage

Beck, Ulrich and Grande, Edgar 2010. Varieties of Second Modernity: The Cosmopolitan Turn in Social and Political Theory and Research', British Journal of Sociology 61(3): 40943.

Beck, Ulrich and Lau, Christophe 2005. Second modernity as a research agenda: theoretical and empirical explorations in the 'meta-change' of modern society British Journal of Sociology 56: (4) 525-54

Bennett, Andy and Taylor, Jodie. 2012. Popular music and the aesthetics of ageing. Popular Music, 31[2]: 231-243.

Castells, Manuel. 1996. The Rise of the Network Society. Blackwell Publishers, Oxford.

Deleuze, Gilles and Guattari, Felix. 1980 /2004. A Thousand Plateaus. Continuum Books, London. 
Featherstone, Mike and Hepworth, Mike. 1991. 'The Mask of Ageing and the Postmodern Lifecourse'. In (Eds) Mike Featherstone, Mike Hepworth and Bryan S. Turner. The Body, Social Process and Cultural Theory. London: Sage Publications, 371-89.

Featherstone, Mike, Hepworth, Mike and Turner, Bryan. 1991 The Body, Social Process and Cultural Theory. London: Sage Publications

Figari, Francesco, Matsaganis, Manos and Sutherland, Holly. 2011. The financial well-being of older people in Europe and the redistributive effects of minimum pension schemes, EUROMOD Working Paper, No. EM7/11. Institute for Social and Economic Research (ISER), University of Essex.

Foucault, Michel. 1994. The ethic of care for the self as a practice of freedom: An interview translated by J.D. Gauthier. In Bernauer, James and Rasmussen, David (Eds). The Final Foucault, MIT Press, Cambridge, Mass, 1-20.

Giddens, Anthony. 1991. Modernity and Self-Identity. Polity Press, Cambridge.

Giddens, Anthony. 1994. Beyond Left and Right. Polity Press, Cambridge.

Gilleard, Chris and Higgs, Paul. 2011a. The Third Age as a cultural field. In (eds.) Dawn Carr and Kathrin Komp. Gerontology in the Era of the Third Age. New York, Springer, 33-50. 
Gilleard, Chris \& Higgs, Paul. 2011b. Consumption and aging. In (eds.) Setterson, Richard and Angel, Jacqueline L. Handbook of Sociology of Aging, Springer, New York, 361-375.

Gilleard, Chris and Higgs, Paul. 2013. Ageing, Corporeality and Embodiment. Anthem Press, London.

Gough, Orla and Niza, Claudia. 2011. Retirement saving choices: Review of the literature and policy implications. Population Ageing, 4: 97-117.

Grech, Aaron George. 2013. How best to measure pension adequacy. MPRA Paper No. 46126.Munich Personal RePEc Archive, University of Munich. (via http://mpra.ub.unimuenchen.de/46126/, accessed April 16 ${ }^{\text {th }}$ 2013).

Hess, Beth B. 1993. Afterword: a personal reflection. Journal of Aging Studies, 7 [2]:195-196

Higgs, Paul and Formosa, Marvin 2013 'The changing significance of social class in later life' In (Eds.) Marvin Formosa and Paul Higgs. Social class in later life: Power, identity and lifestyle. Policy Press, Bristol, 169-181.

Hodkinson, Paul. 2013. Spectacular youth cultures and ageing: Beyond refusing to grow up. Sociology Compass, 7 (1): 13-22.

Hyde, Martin and Jones, Ian Rees. 2013. Social class, age and identity in later life. In (eds) Marvin Formosa and Paul Higgs. Social class in later life: Power, identity and lifestyle. Policy Press, Bristol, 73-94. 
Kohli, Martin 2007 The Institutionalization of the Life Course: Looking Back to Look Ahead Research in Human Development 4 (3-4): 253-271.

Olson, Laura Katz. 1988. Aging is a woman's problem: Issues faced by the female elderly population. Journal of Aging Studies, 2 (2): 97-108.

Outhwaite, William. 2009. Canon formation in late 20th-Century British sociology. Sociology, 43 (6): 1029-1045.

Sontag, Susan. 1972. The double standard of aging. Saturday Review, 23 September, 29-38.

Twigg, Julia. 2013. Fashion and Age: Dress, the body and later life. Bloomsbury Publishing, London.

United Nations Economic Commission for Europe. 2009. Older Persons as Consumers. UNECE Policy Brief on Ageing No. 3: Geneva, UNECE.

Venn, Susan, Davidson, Kate and Arber, Sara. 2011. Gender and Aging, In (Eds.) Setterson, Richard and Angel, Jacqueline L. Handbook of Sociology of Aging, Springer, New York, 361 Wolff, Edward N., Zacharias, Ajit and Masterson, Thomas. 2012. Trends in American living standards and inequality, 1959-2007. Review of Income and Wealth, 58 (2): 197-232.

Zaidi, Asghar. 2009. Poverty and Income of Older People in OECD Countries. Available at http://ssrn.com/abstract=1992492 or http://dx.doi.org/10.2139/ssrn.1992492. 
Zaidi, Asghar. 2010. Fiscal and Pension Sustainability: Present and Future Issues in EU Countries. Policy Brief Series, European Centre, Vienna.

Word count: 4492 